\title{
Leprosy and ABO Blood Groups
}

\author{
GURMOHAN SINGH and DIVAKAR OJHA
}

\author{
From the College of Medical Sciences, Banaras Hindu University, Varanasi-5, India
}

The present study records the distribution of the ABO system of blood groups in 633 leprosy patients as compared with that seen in the general population.

\section{Material and Methods}

Cases were selected from the Skin Out-patients Department and Leprosy Clinic of S.S. Hospital, Banaras Hindu University and the Leprosy Clinic at Chowka Ghat, Varanasi. Patients belonging to any other province or country were excluded. Blood was grouped by the slide method described by Stratton and Renton (1958). The control material consisted of data on 2583 recipients of blood at the hospital. Typing of leprosy was on clinical criteria, supported by bacteriological examination and histopathological studies in disputed cases.

\section{Results}

Table I shows the distribution of ABO blood groups in two groups of leprosy patients set against the data for the controls. It will be seen that when the total of leprosy patients is compared with the controls, the value of $\chi^{2}$ is 2.51 . This is not significant as the tabular values of $\chi^{2}$ for three degrees of freedom are $7 \cdot 815$ (at $5 \%$ probability level) and $6 \cdot 251$ (at $10 \%$ probability level).

Likewise, if lepromatous leprosy and non-lepromatous leprosy patients are compared with the controls the values of $\chi^{2}$ are $3 \cdot 70$ and $2 \cdot 835$, respectively (d.f. 3), which are also not significant.

Heterogeneity. The lepromatous and non-lepromatous series of cases do not differ significantly in the pattern of $\mathrm{ABO}$ blood groups.

$\chi^{2}=(3.7+2 \cdot 835)-2 \cdot 51=4.025($ d.f. $=3) \mathrm{p}<0.250$,

\section{Discussion}

Studies on the ABO system of blood groups in leprosy in India have come from Lowe (1942), Hsuen, Thomas, and Jesudian (1963), Verma and Dongre (1965), Gupta and Gupta (1966), and

Received January 3, 1967.
Povey and Horton (1966). Contributions from abroad have come from Sato (1949), Beiguelman (1963, 1964), Yankah (1965), and Lechat (1965).

Apart from Hsuen et al. (1963), almost all observers appear to think that there is no difference in $\mathrm{ABO}$ blood group pattern between members of the general population and leprosy patients. The higher incidence of leprosy in group $O$ and the

\section{TABLE I}

DISTRIBUTION OF ABO BLOOD GROUPS IN LEPROSY PATIENTS AND CONTROL MATERIAL

\begin{tabular}{|c|c|c|c|c|c|c|c|c|}
\hline \multirow{3}{*}{ Group } & \multirow{2}{*}{\multicolumn{2}{|c|}{$\begin{array}{c}\text { Control Series } \\
\text { of Consecutive } \\
\text { Recipients of } \\
\text { Blood (Singh } \\
\text { and Shanker, } \\
\text { 1966) }\end{array}$}} & \multicolumn{4}{|c|}{ Leprosy Patients } & \multirow{2}{*}{\multicolumn{2}{|c|}{ Total }} \\
\hline & & & \multicolumn{2}{|c|}{ Lepromatous } & \multicolumn{2}{|c|}{$\begin{array}{c}\text { Non- } \\
\text { lepromatous }\end{array}$} & & \\
\hline & No. & $\%$ & No. & $\%$ & No. & $\%$ & No. & $\%$ \\
\hline $\begin{array}{l}\mathbf{A} \\
\mathbf{B} \\
\mathbf{O} \\
\mathbf{A B}\end{array}$ & $\begin{array}{l}639 \\
859 \\
873 \\
212\end{array}$ & $\begin{array}{r}24 \cdot 74 \\
33 \cdot 26 \\
33 \cdot 80 \\
8 \cdot 20\end{array}$ & $\begin{array}{l}54 \\
51 \\
47 \\
12\end{array}$ & $\begin{array}{r}32 \cdot 92 \\
31 \cdot 10 \\
28 \cdot 66 \\
7 \cdot 32\end{array}$ & $\begin{array}{r}139 \\
121 \\
165 \\
44\end{array}$ & $\begin{array}{r}29 \cdot 63 \\
25 \cdot 80 \\
35 \cdot 19 \\
9 \cdot 38\end{array}$ & $\begin{array}{r}193 \\
172 \\
212 \\
56\end{array}$ & $\begin{array}{r}30.49 \\
27.17 \\
33.50 \\
8.84\end{array}$ \\
\hline Total & 2583 & $100 \cdot 00$ & 164 & $100 \cdot 00$ & 469 & $100 \cdot 00$ & 633 & $100 \cdot 00$ \\
\hline
\end{tabular}

TABLE II

TOTAL OF $x^{2}$ DISTRIBUTIONS CALCULATED FROM DIFFERENT REPORTS AND PROBABILITY VALUES

\begin{tabular}{|c|c|c|c|c|c|}
\hline \multirow[b]{2}{*}{ Reference } & \multicolumn{2}{|c|}{$\begin{array}{l}\text { All Cases of } \\
\text { Leprosy }\end{array}$} & \multirow{2}{*}{$\begin{array}{c}\text { Lepro- } \\
\text { matous } \\
\qquad \chi^{2}\end{array}$} & \multirow{2}{*}{$\begin{array}{c}\text { Non- } \\
\text { lepro } \\
\text { matous } \\
x^{2}\end{array}$} & \multirow{2}{*}{$\begin{array}{c}\text { Degrees } \\
\text { of } \\
\text { Free- } \\
\text { dom }\end{array}$} \\
\hline & $\chi^{2}$ & $\begin{array}{c}\text { Degrees } \\
\text { of } \\
\text { Free- } \\
\text { dom }\end{array}$ & & & \\
\hline $\begin{array}{l}\text { Hsuen } \text { et al. } \\
\text { (1963) } \\
\text { Yankah (1965) } \\
\text { Verma and } \\
\text { Dongre } \\
\text { (1965) } \\
\text { Gupta and } \\
\text { Gupta (1966) } \\
\text { Povey and } \\
\text { Horton } \\
\text { (1966) } \\
\text { Present series }\end{array}$ & $\begin{array}{l}6.832 \\
0.610 \\
\\
7.860 \\
2.569 \\
\\
0.775 \\
2.510\end{array}$ & $\begin{array}{l}3 \\
3\end{array}$ & $\begin{array}{c}4 \cdot 639 \\
6 \cdot 840 \\
6 \cdot 090 \\
-\end{array}$ & $\begin{array}{l}9 \cdot 247 \\
3 \cdot 720 \\
5 \cdot 030 \\
-\end{array}$ & $\begin{array}{r}3 \\
3 \\
\\
3 \\
-\end{array}$ \\
\hline Total & $21 \cdot 156$ & 18 & $21 \cdot 975$ & 21.902 & 15 \\
\hline
\end{tabular}


lower incidence in group B patients, as observed by Hsuen et al. (1963) in their series, has been thought by Povey and Horton (1966) to be due to a difference in stock between patients and controls.

Beiguelman (1963), studying different racial samples, observed a higher incidence of tuberculous leprosy in group $\mathrm{O}$ patients; but there was no difference in incidence when tuberculous and lepromatous patients were compared within each racial group (which is more appropriate). Beiguelman (1964) also found a predominance of lepromatous leprosy patients in group A and a slight excess of tuberculous patients in group $O$. Our results do not show any such relationship.

Taking the sum total of observations recorded in the English published reports, it is clear that there is no strong evidence of influence of $\mathrm{ABO}$ blood groups on the course of leprosy (Table II). The tabular value of $\chi^{2}$ for 18 degrees of freedom is 21.6 (at $25 \%$ ), for 15 degrees of freedom 25.0 (at $5 \%$ ) and 22.3 (at $10 \%$ ). It is thus obvious that the frequency distribution of blood groups in leprosy as a whole or in tuberculous leprosy patients separately does not differ from that in the general population.

\section{Summary}

ABO blood groups were studied in 633 leprosy patients and compared with 2583 controls. No re- lation between blood groups and susceptibility to disease was observed. Lepromatous and nonlepromatous groups of patients did not differ significantly as regards pattern of $\mathrm{ABO}$ blood groups.

We wish to thank Dr. K. N. Udupa, M.S., F.R.C.S. Superintendent S.S. Hospital, and Principal, College of Medical Sciences, for his permission to publish this report.

\section{REFERENCES}

Beiguelman, B. (1963). Grupos sanguíneos e lepra. Rev bras. Leprol., 31, 34

(1964). Sistema ABO e epidemiologia de lepra. Rev. paul. Med., 65, 80.

Gupta, M. C., and Gupta, S. R. (1966). Blood groups in relation to pulmonary tuberculosis and leprosy. Indian $\mathcal{F}$. med. Sci., 20, 353

Hsuen, J., Thomas, E., and Jesudian, G. (1963). ABO blood groups and leprosy. Leprosy Rev., 34, 143.

Lechat, M. F. (1965). Methodology of genetic study in the epidemiology of leprosy. Int. F. Leprosy, 33, 744. (Also quoted by Blumberg, B.S., 1965, Leprosy research through genetics. Int. F. Leprosy, 33, 739.)

Lowe, J. (1942). Leprosy and blood groups. Leprosy in India, 14, 23.

Povey, M.S., and Horton, R. J. (1966). Leprosy and blood groups. Leprosy Rev., 37, 147.

Sato, E. (1949). ABO blood groups and secretion especially in relation to familial leprosy. Lepro, 18, 65. (In Japanese.)

Singh, G., and Shanker, P. (1966). Vitiligo and blood groups. Brit. F. Derm., 78, 91.

Stratton, F., and Renton, P. H. (1958). Practical Blood Grouping. Blackwell, Oxford.

Verma, B. S., and Dongre, A. V. (1965). Leprosy and ABO blood groups. Leprosy Rev., 36, 211.

Yankah, J. A. K. (1965). Observation on the frequency of ABO and $\mathrm{Rh}$ blood groups in leprosy and non-leprosy people in Ghana. ibid., 36, 73 . 